\title{
Brain changes in subjects with catastrophic pain, as detected by magnetic resonance imaging: A systematic review
}

\author{
Ana Izabela S de Oliveira-Souza ${ }^{*}$, Josepha Karinne de O Ferro ${ }^{1}$, Manuella MMB Barros ${ }^{1}$, Paula RB Diniz ${ }^{2}$ and Daniella A de Oliveira $^{3}$ \\ ${ }^{1}$ Neuropsychiatry and Behavioral Sciences, Universidade Federal de Pernambuco, Recife, PE, Brazil \\ ${ }^{2}$ Telehealth Center, Internal Medicine Department, Health Sciences Center, Universidade Federal de Pernambuco, Recife, PE, Brazil \\ ${ }^{3}$ Department of Physical Therapy, Health Sciences Center, Universidade Federal de Pernambuco, Recife, PE, Brazil
}

\begin{abstract}
Background: There is evidence of the association between catastrophic pain and cerebral connectivity activation. However, the nature of such neural network changes, and brain regions that are most likely to be affected are still unknown.

Objective: To summarize the data available in the literature regarding fMRI-detected brain changes in individuals with catastrophic pain.

Methods: This review included searches across the following databases: Medline-via-PubMed, Web-of-Science and Scopus. We included: cross-sectional studies; fMRI studies using the catastrophic pain scale; and control groups with healthy individuals. We measure the quality evaluation of the selected studies using the New Castle-Ottawa Quality Assessment Scale.

Results: In total, 339 articles were identified, and after the title and abstract selection, 11 references were selected for further evaluation. Unfortunately, seven works were excluded by the eligibility criteria. Thus, a total of four studies were included for qualitative analysis: two included migraine subjects; one fibromyalgia; and another temporomandibular dysfunction. The included articles presented moderate quality of evidence.

Conclusions: In healthy subjects, repeated exposure to painful stimuli generates a specific perception of pain with increased functional connectivity and somatosensory network activity. This does not happen in high catastrophic scores patients, instead may acquire a pain-associated increased state of attention and the inability to direct their attention to other situations, leading to reduced pain modulation capacity. This review finds a change in functional connectivity during processes of rumination or negative pain perception in the anterior and posterior cingulate cortex, somatosensory cortex, medial prefrontal cortex, thalamus, insula, pre-cuneus, midbrain, and retrosplenial cortex.
\end{abstract}

\section{Introduction}

The International Association for the Study of Pain (IASP) defines chronic pain as discomfort with no biological cause that persists for longer than tissue healing [1]. Epidemiological data demonstrate that chronic pain is present in approximately $2-40 \%$ of the world population. This wide range in chronic pain prevalence is justified by the different ways of evaluating pain symptomatology [2]. Painful formation and processing involve complex mechanisms requiring cognition, perception, and emotion [3], while psychological factors have also been linked to the chronicity of pain [4]. Areas such as the anterior cingulate cortex, thalamus, basal ganglia and the insula have been associated with the pain perception and may undergo structural or circuitry-related changes in subjects suffering from this dysfunction [5].

The cognitive and emotional aspects of chronic pain sensation, involve catastrophic pain-related thinking, defined as a negative state in the face of a painful experience [6]. Catastrophic pain particularly relates to thoughts and feelings associated with the painful situation, such as fear, worry and inability to divert attention and handle the pain [7].

Individual levels of catastrophic pain were associated with a decrease in pain anticipation-related cerebral activity, as assessed by neuroimaging. This reduced cerebral activity contributed to hyperalgesia in fibromyalgia patients [8]. Moreover, it has been suggested that catastrophic pain is related to nociception and that together with the patient's psychological perspective can modulate noxious stimulus perception, thus altering neural activity patterns [9].

Patients who present with a higher level of catastrophic pain seem to have increased cortical activity in response to painful stimuli that involves the posterior cingulate cortex, the anterior insula and the cerebellum [9]. There is accumulating evidence that catastrophic pain activates the somatosensory cortex, prefrontal cortex, cingulate cortex and the hippocampus [10]. However, catastrophic pain is not associated with changes in periaqueductal gray matter activation [11].

The literature presents evidence of the association between catastrophic pain and cerebral connectivity activation, as detected by

${ }^{\star}$ Correspondence to: Ana Izabela S. de Oliveira-Souza, Rua Francisco da Cunha, 1325 (apto 403) - Boa Viagem, Recife - PE, 51020-041, Brazil, Tel: +55 81 981421230; E-mail address: anaizabela.oliveira@hotmail.com.

Key words: catastrophizing; magnetic resonance image; neuroimaging; brain mapping

Received: May 17, 2019; Accepted: May 27, 2019; Published: May 30, 2019 
functional magnetic resonance imaging (fMRI). However, the precise nature of such neural network changes, as well as the brain regions that are most likely to be affected are still unknown. Therefore, the aim of this review is to summarize the data available in the literature regarding fMRI-detected brain changes in individuals with chronic catastrophic pain.

\section{Methods}

Cross-sectional literature searches were conducted in the following databases: Medline via PubMed, Web of Science, and Scopus. We used articles without publication date and linguistic restrictions. The MESH descriptors used were: "catastrophization", "catastrophizing", "magnetic resonance image", "neuroimaging", "brain mapping", combined with the Boolean operator "AND". This review has registration number CRD42018090379.

The search period was from April to August 2017, and three independent reviewers searched: A.I.S.O.S, J.K.O.F, M.M.M.B.B., who accessed and identified articles from titles and abstracts according to the eligibility criteria. In case of doubt, the studies were selected for further full-text analysis.

The inclusion criteria were cross-sectional studies using fMRI, catastrophic pain scale and that had included control groups with healthy individuals. Studies with subjects younger than 18 years, pregnant or that used other brain imaging assessments were excluded from this study. The article selection flowchart follows the Preferred Reporting Items for Systemic Reviews and Meta-Analysis (PRISMA) model (Figure 1).

Quality evaluation of the selected studies was performed by three independent reviewers using the New Castle-Ottawa quality assessment scale (NOS) for cross-sectional studies. This tool analyzes articles according to (a) selection (sample representativeness, sample size, subjects who did not respond, exposure/risk factors); (b) comparability; and (c) outcomes (evaluation of results and statistical analysis). The NOS qualitative analysis is performed using a complete classification of 10 stars, distributed in three domains: selection (maximum five stars), comparability (maximum two stars) and outcomes (maximum three stars). The higher number of stars obtained, the better the methodological quality of the study.

\section{Results}

We identify a total of 339 articles from the database search, and after initial screening based on the title and abstract, 11 references were selected for further reading. Unfortunately, we excluded seven paper because they did not comply the eligibility criteria and one because it did not use a control group with healthy individuals. Thus, a total of four studies were included for qualitative analysis (Figure 1).

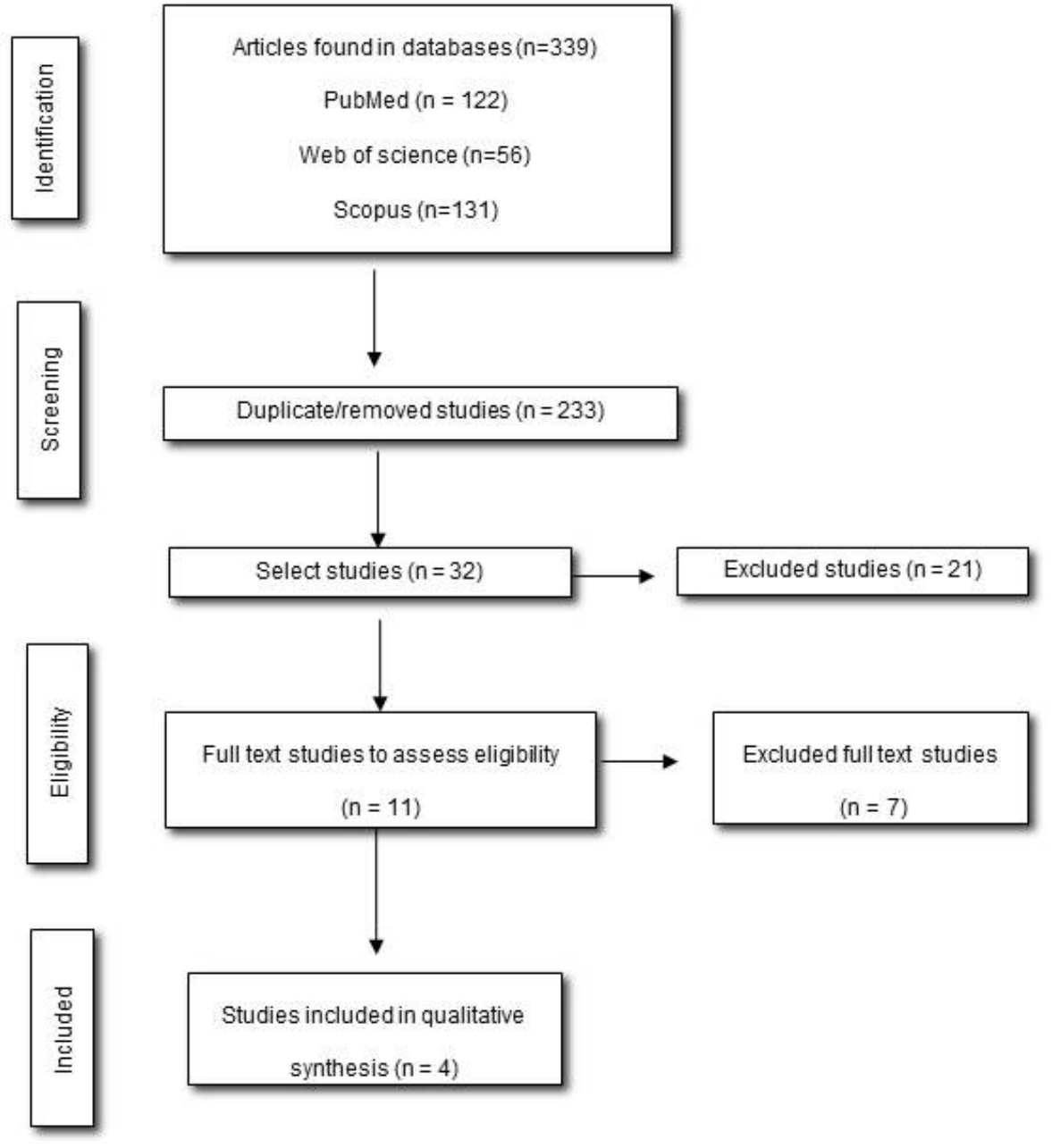

Figure 1. Flowchart and criteria for selection and inclusion of articles 
Table 1. Methodological quality evaluation of included studies according to New Castle - Ottawa quality assessment scale / cross section studies (NOS).

\begin{tabular}{|c|c|c|c|c|}
\hline NOS assessment $(10 *)$ & Hubbard et al. [11] & Kucyi et al. [15] & Mathur et al. [16] & Kim et al. [17] \\
\hline \multicolumn{5}{|l|}{ SELECTION } \\
\hline Representativeness & - & - & - & - \\
\hline Sample size & - & - & - & - \\
\hline Non-respondents & - & - & $*$ & - \\
\hline Ascertainment of the exposure & $* *$ & $* *$ & $* *$ & $* *$ \\
\hline Comparability & $*$ & $*$ & $*$ & $*$ \\
\hline Assessment of outcome & $* *$ & $* *$ & $* *$ & $* *$ \\
\hline Statistical test & $*$ & - & - & - \\
\hline TOTAL & $* * * * * *$ & $* * * * *$ & $* * * * * *$ & $* * * * *$ \\
\hline
\end{tabular}

Table 2. Characteristics of included studies.

\begin{tabular}{|c|c|c|c|c|c|c|c|}
\hline $\begin{array}{l}\text { Authors / } \\
\text { year }\end{array}$ & $\begin{array}{l}\text { Groups } \\
\text { n }(\mathbf{M} / \mathbf{W})\end{array}$ & $\begin{array}{l}\text { Age (years) } \\
\pm \text { Standard } \\
\text { deviation }\end{array}$ & Inclusion Criteria & Exclusion criteria & Assessment & $\begin{array}{l}\text { Activities } \\
\text { during fMRI }\end{array}$ & Results \\
\hline $\begin{array}{l}\text { Hubbard et } \\
\text { al. [11] }\end{array}$ & $\begin{array}{l}\text { a) Migraine } \\
n=17(4 / 13) \\
\text { b) Control } \\
n=18(4 / 14)\end{array}$ & $\begin{array}{l}\text { a) Migraine = } \\
41.71 \pm 12.2 \\
\text { b) Control }= \\
38.89 \pm 11.25\end{array}$ & $\begin{array}{l}\text { 1) Patients with recurrent } \\
\text { headache history for at least } \\
\text { three months and monthly } \\
\text { frequency }>4\end{array}$ & -- & $\begin{array}{l}\text { fMRI (Siemens } 3 \text { T Tim Trio } \\
\text { MRI) with T1-weighted } \\
\text { images (144 slices, field-of- } \\
\text { view [FOV]: } 230 \mathrm{~mm} \text {, echo } \\
\text { time [TE]: } 3.44 \mathrm{~ms} \text {, repetition } \\
\text { time [TR]:2500 ms, flip angle: } \\
9.0^{\circ} \text {, resolution: } 0.9 \times 0.9 \mathrm{~mm} \text {, } \\
\text { matrix size: } 256 \times 256 \mathrm{~mm}, \\
\text { slice thickness: } 1 \mathrm{~mm} \text {, no gap) } \\
\text { and T2-weighted (spin-echo, } \\
194 \mathrm{volumes,} 36 \text { slices, FOV: } \\
230 \mathrm{~mm} \text {, } \\
\text { TE: } 30 \text { ms, TR: } 2500 \mathrm{~ms} \text {, flip } \\
\text { angle: } 90^{\circ} \text {, matrix size: } 128 \times \\
128 \mathrm{~mm} \text {, resolution: } 1.8 \times 1.8 \\
\text { mm, slice thickness: } 4 \mathrm{~mm}, \text { no } \\
\text { gap, oblique slices) }\end{array}$ & \begin{tabular}{|l|} 
\\
Rest \\
$v s$ \\
Cognitive task \\
related to pain \\
\\
\end{tabular} & $\begin{array}{l}\begin{array}{l}\text { Structural } \\
\text { (reduction of gray } \\
\text { matter): }\end{array} \\
\text { - Left primary } \\
\text { somatosensory } \\
\text { cortex, left } \\
\text { prefrontal medial } \\
\text { cortex, Left } \\
\text { anterior cingulate } \\
\text { middle cortex } \\
\\
\uparrow \text { Functional } \\
\text { connectivity: } \\
\text { - Bilateral } \\
\text { dorsolateral } \\
\text { prefrontal cortex, } \\
\text { posterior cingulate } \\
\text { cortex; }\end{array}$ \\
\hline $\begin{array}{l}\text { Kucyi et al. } \\
{[15]}\end{array}$ & $\begin{array}{l}\text { a) TMD } \\
\mathrm{n}=17(0 / 17) \\
\text { b) Control } \\
\mathrm{n}=17(0 / 17)\end{array}$ & $\begin{array}{l}\text { a) } \mathrm{TMD}= \\
33.1 \pm 11.9 \\
\\
\text { b) Control = } \\
33.2 \pm 10.2\end{array}$ & $\begin{array}{l}\text { (1) DTM non-traumatic } \\
\text { (2) Muscle pain in the } \\
\text { temporomandibular area; } \\
\text { (3) Pain in chewing muscles } \\
\text { assessed verbally with at least } \\
\text { 4/10 for at least three months } \\
\text { (4) Pain at palpation and/ } \\
\text { or persistent severe pain } \\
\text { after feeding in at least three } \\
\text { muscles; and/or moderate } \\
\text { pain during palpation of the } \\
\text { joint temporomandibular } \\
\text { and/or limited mandibular } \\
\text { movement (opening } 40 \mathrm{~mm} \text { ) }\end{array}$ & $\begin{array}{l}\text { (1) left handed } \\
\text { (2) Self-report of metabolic, } \\
\text { rheumatic, vascular or other serious } \\
\text { diseases } \\
\text { (3) self-report of functional chronic } \\
\text { pain disorders (irritable bowel } \\
\text { syndrome and fibromyalgia) } \\
\text { (4) self-report of psychiatric disorders } \\
\text { (5) abnormal neurological } \\
\text { examination } \\
\text { (6) contraindication to MRI } \\
\text { (7) Substance use. } \\
\text { Healthy controls: history of chronic } \\
\text { pain. }\end{array}$ & $\begin{array}{l}\text { fMRI BOLD (3T GE Signa } \\
\text { HDx MRI system) with T2- } \\
\text { weighted images (TR: } 2000 \\
\text { ms, TE: } 40 \mathrm{~ms} \text {, flip angle: } 45^{\circ} \text {; } \\
28 \text { axial slices per volume, } 64 \\
\times 64 \text { matrix, } 3.125 \times 3.1254 \\
\text { mm }^{3} \text { voxels) and T1-weighted } \\
\text { images in three-dimensional } \\
\text { sequence (TR: } 12 \mathrm{~ms} \text {, TE: } 5 \\
\text { ms, TI: } 300 \mathrm{~ms}, \text { flip angle: } \\
20^{\circ}, 128 \text { axial slices, } 256 \times \\
256 \text { matrix, FOV: } 24 \times 24 \mathrm{~cm} \text {, } \\
0.94 \times 0.941 .5 \mathrm{~mm}^{3} \text { voxels) }\end{array}$ & Rest & $\begin{array}{l}\uparrow \text { Functional } \\
\text { connectivity: } \\
\text { - Medial prefrontal } \\
\text { cortex, left } \\
\text { posterior cingulate } \\
\text { cortex, anterior } \\
\text { and medial } \\
\text { thalamus, right } \\
\text { cuneus, midbrain } \\
\text { and retrosplenial } \\
\text { cortex }\end{array}$ \\
\hline $\begin{array}{l}\text { Mathur et al. } \\
{[16]}\end{array}$ & $\begin{array}{l}\text { a) Migraine = } \\
\mathrm{n}=14(3 / 11) \\
\text { b) Control }= \\
\mathrm{n}=14(3 / 11)\end{array}$ & $\begin{array}{l}\text { a) Migraine }= \\
40.8 \pm 11.9 \\
\text { b) Control = } \\
38.9 \pm 12.5\end{array}$ & $\begin{array}{l}\text { 1) Migraine patients with } \\
\text { a high frequency of crises } \\
\text { (more days with pain than } \\
\text { days free from pain) } \\
\text { 2) History of recurrent } \\
\text { headache for at least one year }\end{array}$ & $\begin{array}{l}\text { 1) Psychiatric disease } \\
\text { 2) Pregnant women } \\
\text { 3) Use of illicit drugs and } \\
\text { alcoholism } \\
\text { 4) Control with chronic pain }\end{array}$ & $\begin{array}{l}\text { fMRI BOLD (Siemens 3T } \\
\text { Tim Trio) with T2-weighted } \\
\text { images (spin-echo, } 36 \text { slices, } \\
\text { TR: } 2500 \mathrm{~ms}, \text { TE: } 30 \mathrm{~ms} \text {, flip } \\
\text { angle: } 90^{\circ}, \text { FOV: } 230 \mathrm{~mm} \text {, } \\
\text { resolution: } 1.8 \times 1.8 \mathrm{~mm} \text {, } \\
\text { matrix size: } 128 \times 128 \mathrm{~mm} \text {, } \\
\text { slice thickness: } 4 \mathrm{~mm}, \text { no } \\
\text { gap, oblique slices) and T1- } \\
\text { weighted images }(144 \text { slices, } \\
\text { TR: } 2500 \mathrm{~ms}, \text { TE: } 3.44 \mathrm{~ms}, \\
\text { flip angle: } 9.0^{\circ}, \text { FOV: } 230 \\
\text { mm, resolution: } 0.9 \times 0.9 \mathrm{~mm} \text {, } \\
\text { matrix size: } 256 \times 256 \mathrm{~mm} \text {, } \\
\text { slice thickness: } 1 \mathrm{~mm}, \text { no gap) }\end{array}$ & $\begin{array}{l} \\
\\
\text { Rest } \\
v s \\
\text { Painful } \\
\text { thermal } \\
\text { stimulation. } \\
\end{array}$ & $\begin{array}{l}\downarrow \text { Functional } \\
\text { connectivity: } \\
\text { - Medial prefrontal } \\
\text { cortex, caudate, } \\
\text { posterior cingulum } \\
\text { /precuneus; } \\
\\
\uparrow \text { Functional } \\
\text { connectivity: } \\
\text { - Insula anterior }\end{array}$ \\
\hline $\begin{array}{l}\text { Kim et al. } \\
2016 \text { [17] }\end{array}$ & $\begin{array}{l}\text { a) Fibromyalgia } \\
=\mathrm{n}=35(3 / 32) \\
\text { b) Control }= \\
\mathrm{n}=14(4 / 10)\end{array}$ & $\begin{array}{l}\text { a) Fibromyalgia } \\
=44.9 \pm 12 \\
\text { b) Control }= \\
44.2 \pm 14.3\end{array}$ & $\begin{array}{l}\text { 1) Age between 18-70 } \\
\text { years old } \\
\text { 2) Diagnostic of fibromyalgia } \\
\text { 3) Know the criteria proposed } \\
\text { by Wolfe et al. }\end{array}$ & $\begin{array}{l}\text { 1) Neurological and cardiac } \\
\text { diseases, anxiety disorder } \\
\text { 2) History of head injury } \\
\text { 3) Opioid treatment } \\
\text { 4) Drugs users } \\
\text { 5) Contraindication of MRI } \\
\text { 6) Control with acute or chronic } \\
\text { pain and age above the established } \\
\text { limit }\end{array}$ & $\begin{array}{l}\text { fMRI (3T TIM Trio MRI System } \\
\text { Siemens) with T2-weighted } \\
\text { images - BOLD EPI (TR/TE = } \\
2 \text { sec/30 ms, flip angle: } 90^{\circ}, 37 \\
\text { AC-PC aligned axial slices, voxel } \\
\text { size: } 3.1 \times 3.1 \times 3.6 \mathrm{~mm} \text { ) and } \\
\text { T1-weighted images MPRAGE } \\
\text { (TR/TE1/TE2/TE3/TE4 }= \\
2,530 / 1.64 / 3.5 / 5.36 / 7.22 \mathrm{~ms}, \\
\text { flip angle: } 7^{\circ}, \text { voxel size: } 1 \mathrm{~mm} \\
\text { isotropic) }\end{array}$ & \begin{tabular}{|l} 
\\
Rest \\
vs \\
Painful \\
stimulation \\
(pressure)
\end{tabular} & $\begin{array}{l}\uparrow \text { Functional } \\
\text { connectivity: } \\
\text { - Primary } \\
\text { somatosensory } \\
\text { area for bilateral } \\
\text { anterior insula }\end{array}$ \\
\hline
\end{tabular}

FOV: Field of view. 
After careful methodological analysis, the included articles presented moderate quality of evidence. The results are analyzed in table 1 .

In $75 \%$ of the studies, image acquisition was performed either during 'rest' or 'activity' periods in order to reach the pain threshold, as shown in table 2 .

\section{Discussion}

The purpose of the present review was to summarize the data available in the literature regarding fMRI-detected brain changes in individuals with chronic catastrophic pain. In these individuals, there are functional connectivity changes in brain areas modulating the neural circuitry and descending molecular pathways of pain modulation and affective memory. Accumulating evidence from our literature review supports the notion that specific brain areas including the anterior and posterior cingulate cortex, the somatosensory cortex, the medial prefrontal cortex, the thalamus, the insula, the pre-cuneus, midbrain, and the retrosplenial cortex, are activated during processes of rumination or negative pain perception.

Several studies have reported alterations in functional connectivity in chronic pain patients, during attention to introspective thoughts in resting states. This change in the Default Mode Network (DMN), may justify increased basal activity of cognitive or sensorimotor networks in such individuals [12-15]. Corroborating these data, all our included studies on individuals who experienced catastrophic pain, found visible brain changes during neuroimaging examinations in areas related to $\mathrm{DMN}$, such as the medial prefrontal cortex, the posterior cingulate cortex, and the insula.

A positive correlation between pain rumination and functional connectivity of the medial prefrontal cortex was reported, as well as the activation of areas in the posterior cingulate cortex, precuneus, retrosplenial cortex, mesencephalon, dorsomedial and ventral anterior nuclei of the thalamus. These alterations evidence the fact that these individuals associate pain or negative thoughts with emotional and affective aspects [16]. In contrast to these findings, a negative correlation of catastrophic pain with activity in the medial, caudate, prefrontal cortex and the anterior cingulate cortex was observed [17]. The reduction in connectivity that occurs in these regions during nociceptive stimuli has been associated with attentional capture of pain, which is enhanced by the negative rationalization of pain, such as catastrophizing. Despite this difference, the same study also demonstrated a positive correlation of catastrophic pain score to the bilateral activation of the anterior insula, an area responsible for affective and attentional pain processing, thus suggesting the presence of a neurobiological substrate that evokes painful hypersensitivity.

This review enabled the examination of the most activated brain areas in patients with catastrophic pain. However, the main limitation of this study involves the difficulty to develop a meta-analysis due to the heterogeneity of the study sample.

Although catastrophic pain is associated with many psychological factors, the present review demonstrated that patients with catastrophic pain could be anatomical and physiological brain alterations, such as the reduction of gray matter or changes in functional connectivity. Nevertheless, only a few related studies with moderate methodological quality were assessed.

\section{Conclusions}

Repeated exposure to painful stimuli generates a common perception of pain along with increased functional connectivity and somatosensory network activity, suggesting that pain reduction is associated with increased connectivity of the intrinsic sensorimotor network. Patients with high catastrophic scores may have an increased pain-mediated state of attention and the inability to direct their attention to other situations, which may result in reduced pain modulation capacity.

\section{References}

1. Harstall C, Ospina M (2003) How prevalent is chronic pain? IASP Pain Clinical Updates, Vol 6. Seattle, WA: International Association for the Study of Pain.

2. Tsang A, Von Korff M, Lee S, Alonso J, Karam E, et al. (2008) Common Chronic Pain Conditions in Developed and Developing Countries: Gender and Age Differences and Comorbidity with Depression-Anxiety Disorders. J Pain 9: 883-891. [Crossref]

3. Smallwood RF, Laird AR, Ramage AE, Parkinson AL, Lewis J, et al. (2013) Structural brain anomalies and chronic pain: A quantitative meta-analysis of gray matter volume. $J$ Pain 14: 663-675. [Crossref]

4. Simons LE, Elman I, Borsook D (2014) Psychological processing in chronic pain: A neural systems approach. Neurosci Biobehav Rev 39: 61-78. [Crossref]

5. May A (2011) Structural brain imaging: a window into chronic pain. Neuroscientist 17: 209-220. [Crossref]

6. Sullivan MJ, Thorn B, Haythornthwaite JA, Keefe F, Martin M, et al. (2001) Theoretical perspectives on the relation between catastrophizing and pain. Clin J Pain 17: 52-64. [Crossref]

7. Edwards RR, Cahalan C, Mensing G, Smith M, Haythornthwaite JA (2011) Pain, catastrophizing, and depression in the rheumatic diseases. Nat Rev Rheumatol 7: 216224. [Crossref]

8. Burgmer M, Petzke F, Giesecke T, Gaubitz M, Heuft G, et al. (2011) Cerebral activation and catastrophizing during pain anticipation in patients with fibromyalgia. Psychosom Med 73: 751-759. [Crossref]

9. Lloyd DM, Helbig T, Findlay G, Roberts N, Nurmikko T (2016) Brain Areas Involved in Anticipation of Clinically Relevant Pain in Low Back Pain Populations with High Levels of Pain Behaviour. J Pain 17: 577-87. [Crossref]

10. Loggia ML, Berna C, Kim J, Cahalan CM, Martel MO, et al. (2015) The Lateral Prefrontal Cortex Mediates the Hyperalgesic Effects of Negative Cognitions in Chronic Pain Patients. J Pain 16: 692-699. [Crossref]

11. Hubbard CS, Khan SA, Keaser ML, Mathur VA, Goyal M, et al. (2014) Altered Brain Structure and Function Correlate with Disease Severity and Pain Catastrophizing in Migraine Patients. eNeuro 1: e20. [Crossref]

12. Alshelh Z, Marciszewski KK, Akhter R, Di Pietro F, Mills EP, et al. (2017) Disruption of default mode network dynamics in acute and chronic pain states. Neuroimage Clin 17: 222-231. [Crossref]

13. Baliki MN, Geha PY, Apkarian AV, Chialvo DR (2008) Beyond Feeling: Chronic Pain Hurts the Brain, Disrupting the Default-Mode Network Dynamics. J Neurosci 28: 1398-403. [Crossref]

14. Hsiao FJ, Wang SJ, Lin YY, Fuh JL, Ko YC, et al. (2017) Altered insula-default mode network connectivity in fibromyalgia: a resting-state magnetoencephalographic study. J Headache Pain 18: 89. [Crossref]

15. Kucyi A, Moayedi M, Weissman-Fogel I, Goldberg MB, Freeman BV, et al. (2014) Enhanced Medial Prefrontal-Default Mode Network Functional Connectivity in Chronic Pain and Its Association with Pain Rumination. J Neurosci 34: 3969-75. [Crossref]

16. Mathur VA, Moayedi M, Keaser ML, Khan SA, Hubbard CS, et al. (2016) High Frequency Migraine Is Associated with Lower Acute Pain Sensitivity and Abnormal Insula Activity Related to Migraine Pain Intensity, Attack Frequency, and Pain Catastrophizing. Front Hum Neurosci 10:489. [Crossref]

17. Kim J, Loggia ML, Cahalan CM, Harris RE, Beissner F, et al. (2015) The somatosensory link in fibromyalgia: functional connectivity of the primary somatosensory cortex is altered by sustained pain and is associated with clinical/autonomic dysfunction. Arthritis Rheumatol 67: 1395-1405. [Crossref]

Copyright: (C2019 de Oliveira-Souza AIS. This is an open-access article distributed under the terms of the Creative Commons Attribution License, which permits unrestricted use, distribution, and reproduction in any medium, provided the original author and source are credited. 